\title{
動物園的廃棄物の活用法
}

\author{
野田亜矢子 \\ 広島市安佐動物公園 干731-3355 広島市安佐北区安佐町動物園
}

\section{How do We Make Use of Wastes from the Zoo?}

\author{
Ayako NODA \\ Hiroshima city Asa zoological park, Asa-cho,Asakita-ku,Hiroshima 731-3355, Japan
}

\begin{abstract}
Various specimens and materials are pilling up while we are working in the zoo every day. It depends on our attitude to the materials whether these would become "Just waste" or become "Precious specimen and data" . "Research in the zoo by the zoo staff" should be possible if it would has the sense of porpose.Everything in the zoo should stimulates the intellectual curiosity.The zoo staff should make the best use of potencial valuable matters or they would become just waste. Moreover, it is necessary for us to advance "Research" because that is one of the social functions of the zoo.
\end{abstract}

Key words : zoo, zoo staff, wastes, research

Jpn. J.Zoo. Wildl. Med. 14(1) : 27-32, 2009

\section{はじめに}

動物園には教育，レクリエーション，自然保護，研究の 4つ の社会的機能があるとされている [1]。しかし，現在の動物 園はそれを取り巻く環境により，これら全ての役割を満遍なく 果たせているとは言えない状況にある。例えば研究という役割 に目を向けてみよう。日本の動物園はもともとサイエンスを追 求する文化が軽視されがちであった $[2,3]$ 。さらに, 動物園 における獣医師は, いわ伂る知床の現場だけでなく, 衛生管理, 自然保護行政との関わりなど，あらゆる分野に及ぶ業務をこな さなくてはならない。これらの多大な業務の中で「さらに研究 も」となると、沶手上げという部分がなきにしもあらずである。 このように動物園運営の効率化を求められる時代である。そ こで多くの業務とともに「溜まっていく」一方の利用目的の定 まらない膨大な資料や標本類, 目の前に横たわる死体等は, 「必 要のない」ものなのだろうか? 多忙な業務の中では「研究す ること」は難しいことなのだろうか？この問いかけ，動物 園のあり方や，我々動物園の職員のあり方をも問うているので はないだろうか。

本稿では，日頃の動物園活動で派生した事柄を利用し，研究 に供した事例を紹介することにより「動物園に廃充物は存在す るのか?」そして「動物園職員による研究は困難なのか?」と いう問題について，検討してみたい。

\section{事例 1 年間約 30 頭保護収容されるタヌキ(Nyctereutes procyonoides) について}

安佐動物公園では，年間を通じて約 200 件の傷病保護鳥獣 の収容がある。これらの収容動物は, 基本的には野生復帰を目 標として治療，飼育を行うこととなる。当園では，日常業務の 一環として行うのであるが，集めてみると面白い症例にぶつか ることがある。その中からタヌキの事例を紹介したい。

タヌキは年間を通じて約 30 頭程度が，生息密度の高い広島 市内北西部を中心に保護される。初夏の仔ダヌキの誤認保護, 交通事故による外傷などが主な理由である。ある時，交通事故 で搬入されたタヌキの身体検査の際，眼球表面より線虫が発見 された。この線虫はトウヨウガンチュウと同定された。トウヨ ウガンチュウはメマトイ属の昆虫を中間宿主とする寄生線虫で あり, 終宿主はイヌ, ネコ, ウサギ, キツネ, タヌキ, サル, ヒトなど広範囲にわたる [4] ため，タヌキから発見されるこ とは珍しくはないが，広島県内でイヌ，ネコにおける寄生状況 の報告はあったものの [5], 野生動物に関する報告がなかっ たため，調査を開始した。

方法は, 保護・収容されたタヌキについて, 保護地の確認, および眼瞼内の探索を行い, 寄生状況を調査した。その結果, タヌキが保護された地域のほぼ全域からトウヨウガンチュウが 寄生したタヌキが確認された。図 1 に広島市各区内でのタ又 キの保護頭数ならびにトウヨウガンチュウの寄生率（\%) を示 


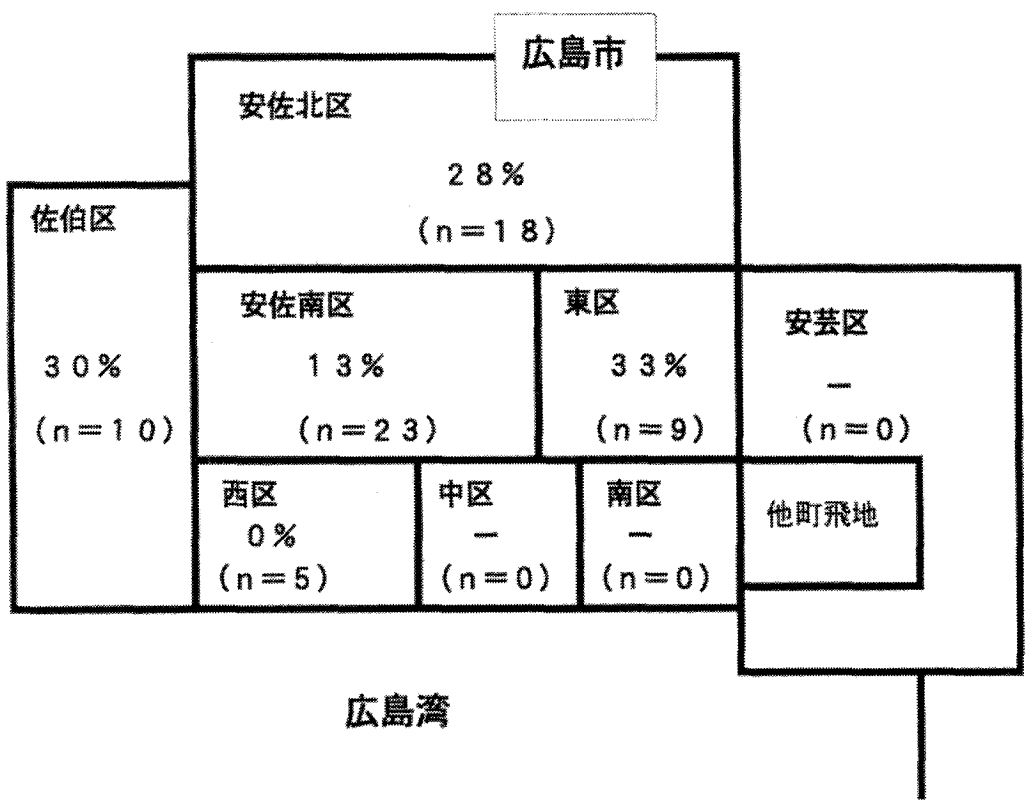

図 1 広島市内各区に拈けるホンドタヌキの保護頭数扔よびトウヨウガンチュ 门の寄生率

す。成獣では地域により最大 $33 \%$ の寄生率であった。この状 況から，広島市内では自然宿主として，タヌキが重要な役割を はたしている可能性が示唆された。

傷病鳥獣として保護収容される動物としては, 珍しくない夕 ヌキであるが，数が蓄積できるからこそできた研究の1つで ある。な扔,この事例は広島県獣医師会雑誌第 22 号 (2007 年) に報告している。

\section{事例 2 プロジェクト「翼をください」}

事例 1 のタヌキ同様，傷病保護で種々の鳥類が収容される。 その収容状況はさまざまで，巣落ちびなの収容，巣立ちびなの 䛊認保護，外傷による衰弱，空などへの衝突などが主な原因で ある。残念なことに，専門の収容施設もなく，専任の職員もい ない現状では，最終的な放鳥率は決して高いとは言えない状況 である。特に治療する間もなく死亡した衝突などのケースでは， 獣医師がまったく手を出すことなく終わることにもなる。しか し, 見方を変えると保護収容により, 種々の鳥類が年間を通じ て持ち込まれるのである。これを生かさない手はない。しかも， 保護值後に死亡したような個体は，胃内容物（食性）や適正体 重などある意味「野生のままの」状態を保っていることになる。 これは「野生動物を飼育」している施設において「本来の野生 動物を知る」ための，きわめて貴重なデータとなり得る。この 事例では，「鳥の飛行能力について」を簡単な航空力学を用い てデータ化した。

材料として，空衝突等で死亡した野鳥 20 種 23 羽を用いた。 航空工学者であるへンク・テネクスはその著書「鳥と飛行機ど
こがちがうか」 [6] の中で，オセアニアに生息する鳥類 196 種について翼面荷重を記している。これを参考に, 各個体の体 重および両翼の面積より翼面荷重を算出した。翼面積は，いず れの鳥についても翼を最大に広げた状態で測定した。小型の鳥 類は直接スキャナにて取り込み， $1 \mathrm{~cm}$ 四方の方眼紙に印刷, 翼が $1 \mathrm{~cm}^{2}$ の方眼を満たしているものは $1 \mathrm{~cm}^{2}$, 満たさないも

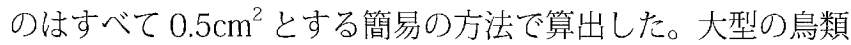
については，翼にスケールをのせた状態でデジタルカメラにて 撮影後，方眼紙に印刷し，スケールの長さから縮尺を算出，小 型の鳥と同様の方法で面積を算出した。死亡時体重を翼面積で 割ったものが翼面荷重である。

また，翼面荷重 $=W / S=0.38 V^{2}$ （W=体重， $S=$ 翼面積, $V=$ 最低飛行速度）から，最低飛行速度が算出されるため，そ れぞれの鳥が理論上どの程度の速度があれば飛びたつことがで きるのかもあわせて算出した。

今回算出した 20 種に扔ける翼面荷重は種によって最小 $0.142 \mathrm{~g} / \mathrm{cm}^{2}$ 〜最大 $1.2 \mathrm{~g} / \mathrm{cm}^{2}$ であった。また，最低飛行速度 は $21.8 \mathrm{~km} / \mathrm{h} \sim 63.3 \mathrm{~km} / \mathrm{h}$ であった。表 1 に調査した種および その体重と翼面荷重および最低飛行速度を示した。これらの数 值はテネケスのデータとほぼ一致しており，簡易な方法での算 出方法であっても，有効なデータとなり得ることが分かった。

航空力学などの分野では，このようなデータが非常に有用で ある。また，鳥の渡り，特に飛行能力についての研究者にとっ ても興味深いデータであろう。しかし，実際にはさまざまな野 鳥の体重や翼面積を実測できる環境というのはきわめて限られ 
動物園的廃棄物の活用法

表 1 検索した野鳥に扔ける体重および翼面荷重

\begin{tabular}{|c|c|c|c|c|}
\hline 鳥 種 & 性 別 & $\begin{array}{c}\text { 体 重 } \\
(\mathrm{g})\end{array}$ & $\begin{array}{l}\text { 翼面荷重 } \\
\left(\mathrm{g} / \mathrm{cm}^{2}\right)\end{array}$ & $\begin{array}{c}\text { 最低飛行速度 } \\
(\mathrm{km} / \mathrm{h})\end{array}$ \\
\hline ムタドリ & $0^{\pi}$ & 64.3 & 0.337 & 33.6 \\
\hline ヒヨドリ & 우 & 80 & 0.357 & 34.5 \\
\hline マミチャジナイ & $0^{\pi}$ & 72 & 0.303 & 31.8 \\
\hline スズメ & $0^{x}$ & 18.6 & 0.198 & 25.7 \\
\hline スズメ（若鳥） & 우 & 18.5 & 0.27 & 30 \\
\hline キビタキ & $\sigma^{7}$ & 12 & 0.185 & 24.9 \\
\hline キビタキ & 우 & 13.5 & 0.18 & 24.5 \\
\hline キジバト & $\sigma^{T}$ & 220 & 0.48 & 40 \\
\hline ツグミ & $\sigma^{x}$ & 88.6 & 0.424 & 37.6 \\
\hline ノスリ & $0^{7}$ & 482 & 0.328 & 33.1 \\
\hline メジロ & 우 & 9.1 & 0.142 & 21.8 \\
\hline カワウ & 우 & 1,400 & 0.972 & 57 \\
\hline カワウ & 우 & 1,440 & 1.03 & 58.7 \\
\hline シロハラ & 우 & 50.8 & 0.213 & 26.7 \\
\hline ミヤマホオジロ & 오 & 22.5 & 0.262 & 29.6 \\
\hline カイツブリ & 우 & 138 & 0.654 & 46.8 \\
\hline コサギ & $0^{x}$ & 492 & 0.372 & 35.3 \\
\hline ハイタカ & $\sigma^{x}$ & 153 & 0.351 & 34.3 \\
\hline ハシボソガラス & $\sigma^{x}$ & 471 & 0.41 & 37 \\
\hline ト ビ & $0^{\pi}$ & 550 & 0.21 & 26.5 \\
\hline ニホンキジ & $0^{x}$ & 1,040 & 1.2 & 63.3 \\
\hline ミサゴ & 不 明 & 1,260 & 0.58 & 44 \\
\hline カワセミ & $0^{x}$ & 27.2 & 0.3 & 31.7 \\
\hline
\end{tabular}

ている。つまり,これらはさまざまな種類の野鳥が保護されて くる動物園ならではのデー夕蓄積と言えるのである。たとえ運 び込まれた時には既に死亡していた，スズメやカラスであって も，こんな利用法もあるのである。

\section{事例 3 八チの子しか食べない低タンパク血症のハチクマ (Pernis apivorus) に給与した代替餉について}

動物園では種々の野生動物が飼育，展示されている。こ扎ら 飼育動物に給与する慨については，野生下と同じものを給与で きるのが理想であるが，実際には入手困難であったり，極めて 高価であったりといった理由で，与えることができないことも 多い。そのため，動物園では代替慨を給与することが少なくな い。本事例では，代替䬣を給䬲することによって，貧血等によ り悪化した全身状態を，一時的に向上させることができた八チ クマの症例を紹介する。

クロスズメバチ類の幼虫等を主食としている猛禽である八チ クマは，中国山地沿いを渡りのコースとしており，広島県内で
も時期になるとよくみられる。症例も，広島市内で外傷により 保護された雌のハチクマで，放鳥を目標に飼育していた個体で ある。飼育 16 か月目に, 多飲多尿の症状を示した後, 2 か月 ほどの間に, 削瘦, 後肢の浮腫, 腹水の眝留などの重篤な症状 を示すに至った。血液検査に抢いても, 高度の貧血, 低タンパ ク血症が認められ，この頃にはそれまで食べていたウズラやヒ ヨコなどを全く食べなくなり，わずかに園内で採集したスズメ バ千類の幼虫, 蛹を食べるのみの状態となった。状態改善のた めには，ストレスを与える可能性の高い強制給慨よりも，嗜好 性が高い慨を給慨する方が良いと判断したものの，八チの子の 入手が困難であったため，嘴好性の高い代替饂を作成すること にした。

代替䬲は外見が八チの子に似たもので，さらに貧血，低タン パク血症を改善し得る栄養素を合んでいるものを作成目標とし た。茹でた卵白を細長く切ったもの,豆腐を細切りにしたもの， 高野豆腐を細切りにしたもの，と試作を重ねた。その結果，高 
野田西矢子

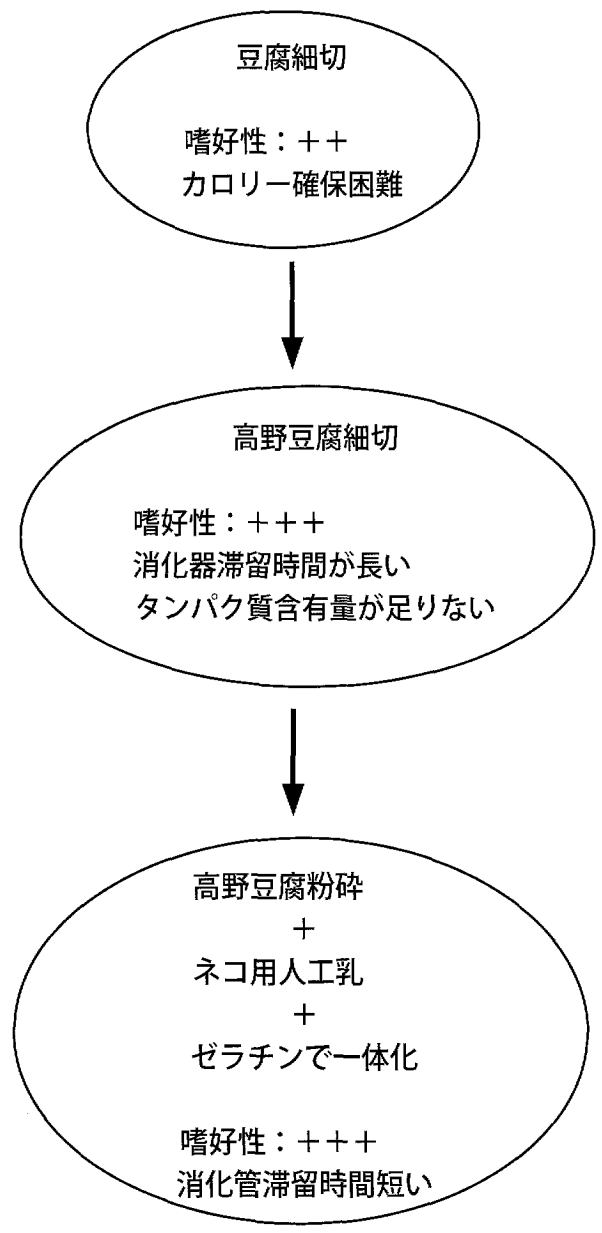

図2 代替慨作成までの経過

野豆腐が最も嗜好性が高かつたが，そ囊への滞留時間が長いと いう久点があった。これらをふまえ，消化管滞在時間を短くす るため，粉砕した高野豆腐に，外見を白く見せ，かつタンパク 質の補充およびカロリー添加を目的としてネコ用人工乳を加え たものを，ゼラチンで固めた代替䬣を完成させた。図 2 に代 替餌作成までの経過を示す。この代替䬣は非常に嗜好性が高く, 給餌開始後 2 か月ほどで血中総タンパク濃度の上昇, 貧血の改 善を認め, 止まり木に止まれない状態だった該当個体が短距離 ながら飛ぶことができるまでの回復をみせた。結果的には, 原 疾患の特定ができず, 代替䬣給餌開始後 2 か月半で死亡したが, 状態の改善がみられるなど，QOLの向上にはつながったと考 えられた。もともとは該当個体が白く細長いものに対して興味 を示したことから始まった代替餌作りであったが，限られた条 件下で野生動物の飼育をする施設ならではのアイディアであっ たのではないかと考えている。

事例 4 飼育係が搾ってきたクロサイ (Diceros bicornis) の乳汁 最後の事例は, 飼育担当者が定期的に搾ってくることのでき
た，クロサイの乳汁について紹介する。動物園で飼育されてい る野生動物は, 希少なものが少なくない。また, 神経質な動物 でも，ある程度人に慣れており，比較的扱いやすい個体になっ ていることもある。このような条件が重なって，連良く貴重な サンプルが採取できることがあるのも動物園ならではと言える だろう。その中の 1 つがクロサイの乳汁であった。かなりの 量が採取されたこともあり, 鼠初は好奇心の赴くまま試飲して みたところ，牛乳との味の違いから，その成分を分析したいと いうことになった。また，過去に安佐動物公園では，クロサイ を人工乳で育てた経験がある。その時にクロサイの乳汁成分が 詳しく分からなかったこともあり, 手探りでウマ用人工乳を利 用した。今後, そのような事態となったときに, 参考にしたい という思いもあった。R. E. Greed らによる報告で, クロサイの 乳汁はきわめて低脂肪であることが分かっているが [7], 継 続的な成分変化の報告はなく, なんとか手軽に, かつ継続的な 成分分析ができないかということでたどり着いたのが，血液生 化学検査機器による乳汁成分分析であった。

検体は安佐動物公園で飼育しているクロサイの第 3 子およ び第 4 子出産時の乳汁で, 出産前の泌乳がみられた時点から 乳汁が出なくなるまでの各 1 年半,ほぼ 1 週間おきに搾乳した。 また, 参考としてウシ (ホルスタイン種), ウマ(ポニー雑種), ヒトの乳汁についても同様の方法で成分分析を行った。検查は フジドライケム3000（富士フィルム株式会社）で血液検查と 同様に検查用スライドに乳汁を $10 \mu 1$ 滴下して行った。検查項 目は総タンパク質濃度 (TP), 中性脂肪濃度 (TG), カルシウ ム濃度（Ca）の3 項目とした。また, 測定上限值を超えたも のについては, 蒸留水で 10 倍希秎した検体で測定した。

表 2 にウシ, ウマ, クロサイおよびヒトの乳汁成分測定値 を示す。また図 3,4 に, クロサイに打ける出産前後の乳汁中 の総タンパク質值の経時的変化を示す。表のように, クロサイ では乳汁中のタンパク質および脂質がウシ，ウマなどの家畜に 比べ低い濃度であることが分かった。また, ウシ, ウマとで比 較した場合にはよりウマのものに近いということが分かり，か つて仔サイの哺乳補助にウマ用人工乳を利用したのは, より良

表 2 各種動物の乳汁成分測定值一覧

\begin{tabular}{lccc}
\hline & $\begin{array}{c}\mathrm{TP} \\
(\mathrm{g} / \mathrm{dl})\end{array}$ & $\begin{array}{c}\mathrm{TG} \\
(\mathrm{mg} / \mathrm{dl})\end{array}$ & $\begin{array}{c}\mathrm{Ca} \\
(\mathrm{mg} / \mathrm{dl})\end{array}$ \\
\hline ヒガシタロサイ & 1.1 & 1,170 & 79 \\
ウシ(ホルスタイン種) & 3.3 & 4,450 & 137 \\
ウマ(ポニー雑種) & 2.6 & 1,890 & 52 \\
ヒト & 1 & 2,760 & 22 \\
\hline
\end{tabular}




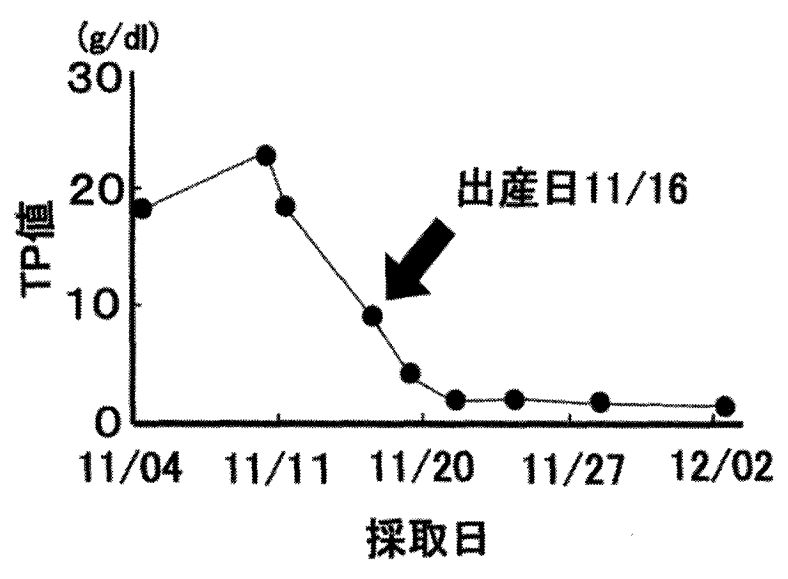

図 3 クロサイの乳汁中 TP 值の変化（2004 年 $/ 3$ 産目）

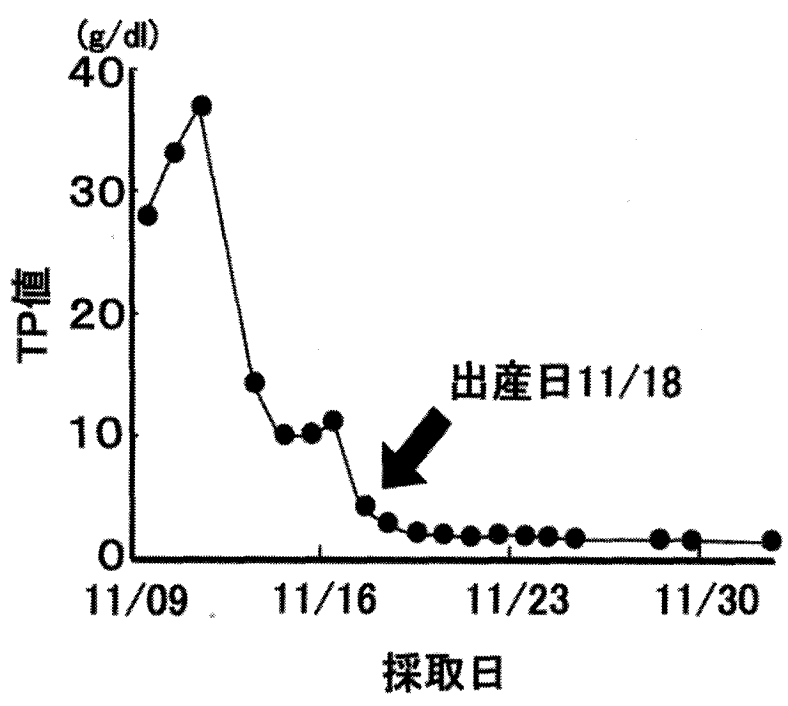

図4 クロサイの乳汁中 TP 值の変化（2006 年 $/ 4$ 産目）

い選択であったことが確認された。さらに，経時的变化では， 他の動物と同じように初乳時期には高タンパク，低脂肪である こと，この時期は出産後数日間であることが分かった。出産前 後の濃度変化は特にタンパク質で顕著であり，極めて高いタン パク質濃度が徐々に低下していき, 最終的には初乳濃度にまで 低下する。したがって出産前からの乳汁成分を測定し, その変 化を見ることで，出産日をある程度推測することが可能である ことも判明した。

このドライケムを利用した乳汁分析は，1 項目が $10 \mu 1$ と非 常に少量で行うことができるということ，さらに手軽に測定で きるという点で，動物園という現場での測定に非常に有用であ ると言える。一方で，この方法は血液検査機器を利用している ため, 乳汁成分としては極めて重要である乳糖などの炭水化物
成分を分析することができないという問題点がある。

しかし，目の前に貴重な検体がありながら，自分たちでは何 もできない，というもどかしい思いを味わった現場の獣医師は 少なくないであろう。自分たちの手で，少しでもデータを収集 することができたら，という思いがこの研究につながったので ある。

\section{動物園に役に立たない派生物は存在するか？}

ある飼育係は 10 年分のビルマニシキへビ (Python molurus bivitatus）の䆏を全て保存している。まさしく廃棄物の山であ る。しかしこの瞥を洗うと，この中からニシキへビの脱落した 歯という宝の山が現れる。この歯の数をカウントすることで, ニシキへビの歯の生え変わりサイクルを知ることができるので ある。つまり，それが廃棄物かどうかは，「物」ではなく，そ れを「报う人」で決まるのである。本来，標本やデータは溜ま ってしまうものではなく,貯めるべきものであり,これらは「意 識」を持った「人」によって生かされる。そして,その「意識」 を持った「人」さえいれば，動物園に「廃棄物は存在しない。 今回紹介した 4 つの事例は，いずれも日くの業務の中で集ま ってきた標本であり,「意識」がなければ埋没してしまったで あろうものばかりである。しかし，ほんの少しのことで，いく つもの発見ができ，さらにそこから発展させて業務に還元する ことができた事例なのである。そして，このことは「動物園の 職員が研究するということ」が，決して特別なことではない， ということを示している。

動物園の役割の 1 つ「研究」の実績が求められるようになり, 動物園が研究に対して積極的になってきたという面がある。一 方で，「共同研究」と称してサンプルを研究機関に提供すれば, 「研究」した気になっている面があるのもまた事実である。も ちろん，限られた施設，時間，予算の中で，自分たちだけでで きることは限られている。それも様々なサンプルを山のように

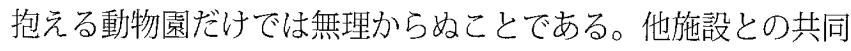
研究も重要であるし，それ無くしては成り立たない。しかし， 目の前にあるサンプルのことを一番よく知っているのは職員自 身である。動物園の職員である以上,そうでなくてはならない。 だからこそ，自分たちでできることを考元，自分たちの手で研 究を行うことはとても重要である。動物園というところは,「意 識」さえあれば知的好奇心をくすぐるものたちであふれかえっ ている。それを生かそうとしないのはあまりにもったいない。 「動物園における動物園職員による研究」は，様々な要因によ り困難を伴うかもしれないが，不可能なことではない。

日々の業務の中で我々の前を通り過ぎて行く命を，さまざま な形で伝えてくこと，与えられた機会を生かすことは，我久動 物園で働く職員に課せられた任務ではないだろうか。 


\section{謝 辞}

本稿をまとめるにあたり，「動物園における研究の重要性」 を理解し，日々協力いただいている職員の皆様に感謝いたしま す。貴重なサンプルを共同で研究していただいている各研究機 関の方々に感謝いたします。また，彼らの存在なくして，これ らの研究がなかった，動物たちに心より感謝いたします。

\section{要 約}

動物園という職場においては, 多大な業務の中で, 種々の標 本や資料が日久溜まっていく。これらが溜まっていく廃棄物」 となるか，それとも「貯められるべき標本やデータ」となるか

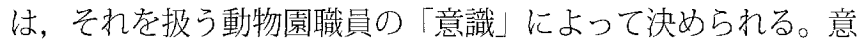
識を持って取り組みさえすれば「動物園職員による研究」は困 難を伴うかもしれないが, 決して不可能なことではない。動物 園という現場は，全てが知的好奇心をくすぐるものであふれて
いる。我々現場で衝くものが，そこここに転がっているである う貴重なサンプルを埋没させることなく科学，そして社会に還 元し, 動物園機能の1つである,「研究」という役割を果たし ていかなくてはならない。

キーワード：動物園, 動物園職員, 廃棄物, 研究

\section{引用文献}

1. 齋藤 勝. 1999. 概論. 新・飼育ハンドブック 動物園編 第 3 集 (社) 日本動物園水族館協会編，p p4. 社)日本動物園水族館協会, 東京.

2. 小原二郎. 1993.動物圆の博物誌, pp229-236. 中国新聞社. 広島

3. 佐々木時雄. 1977. 続動物園の歴史世界霹, pp252-288. 西田書店. 東京.

4. 板垣 博, 大石勇. 1994. 新版家畜寄生虫学, 第10版, pp231-235. 朝含書店. 東京.

5. 鎌倉敬次. 1998. 広島県に扔ける東洋眼虫のイヌ扔よびネコ寄生例発 生状沿. 広島県獣医学杂倠誌 13:63-68.

6. ヘンク・デネケス. 1999. 鳥と飛行機どこがちがうか. 草思社. 東京.

7. Greed RE. 1960. International Zoo Yearbook 2:106. 